\section{INSERM closes the file}

\section{Paris}

"WISDOM and courage have prevailed", says Dr Jacques Benveniste in a letter to the French national newspaper, Le Monde, last week, following the decision on his career taken by Philippe Lazar, director-general of the national institute of health and medical research (INSERM) (see Nature 340, 89; 1989). The two evaluation committees that reviewed the work of Benveniste and his group at Unit 200 were impressed by the overall performance of the laboratory, but both recommended that Benveniste stop his controversial work on high dilutions. As is his right, Lazar did not endorse this recommendation in his four-page letter to Benveniste, but suggested that much of the controversy was due to Nature.

In his letter, Lazar says that the "unprecedented" decision by Nature to organize a laboratory visit after publication of Benveniste's paper, the "oddness" of the visiting panel, the "offensive content" of its conclusions and the "questionable ulterior justifications of the journal regarding its real motivations", constitute extenuating circumstances in Benveniste's case. Lazar expresses surprise at Nature's decision to publish what he calls an "insufficiently founded" paper in the first place. In reply to a question at a press conference last week, Lazar said he would still advise French researchers to submit papers to Nature. "Nature made a false step vis-à-vis this article", he said, "but I hope to God they will not do this again".

Most of the French press has reported the outcome of the four-yearly review of Benveniste's laboratory. But there has

\section{ANIMAL EXPERIMENTS}

\section{Taking advice from experts}

\section{Paris}

ThE French ministries of agriculture, of health and of research have now set up a national commission on animal experimentation, as embodied in legislation which came into force in October 1987. The commission comprises eight representatives from the ministries concerned with animal experimentation (research, agriculture, health, industry, defence, environment and education) and twelve experts drawn from both the public and the private sectors. The commission will advise the government on all questions concerning animal experimentation, but especially on animal husbandry, training of researchers and technicians and the possibilities of finding experimental models that do not require animals.

Peter Coles been little sign of the passions aroused last year, when accusations of "froggy-bashing" were abundant. Indeed, at the press conference, Lazar appealed to the press to "let Dr Benveniste get on with his work" Benveniste was advised by Lazar to avoid speaking to the press. But in his letter to Le Monde, Benveniste was keen to have the last word, accusing Nature of having hit first. Nature, he says, caused a "con-

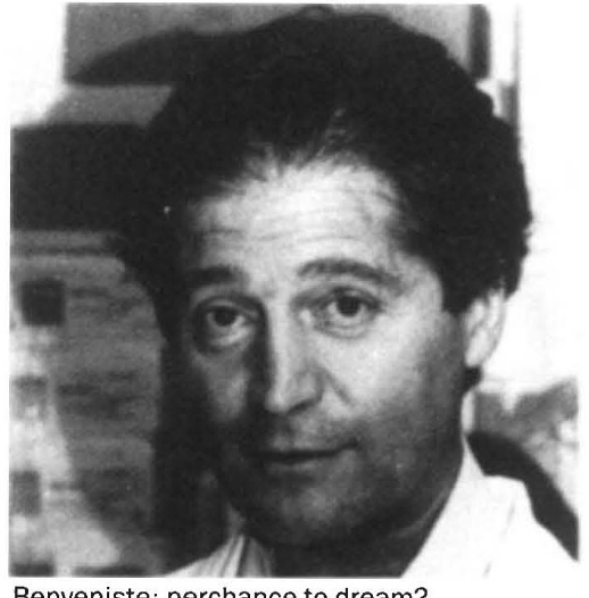

Benveniste: perchance to dream?

siderable media stir", both within and outside the journal. "I followed", he adds.

The tone of the reports of the two evaluation committees is severe. The scientific committee's report, dated 4-6 July, suggests that the controversy surrounding Benveniste's work could "harm the credibility" of the overall work of his group. They say that Benveniste's interpretations were "out of proportion with the facts", and appear as "a laboratory curiosity to which satisfactory explanations have not yet been given and whose import will remain limited". They ask INSERM not to continue to fund highdilution research.

Lazar has not asked Benveniste to stop work on high dilutions, although he made it apparent that this could be incompatible with the ethics of research that Benveniste must respect if his post is to be renewed at the end of the year. Such an injunction, he says, would be contrary to the freedoms accorded to a laboratory director. But he does ask Benveniste systematically to look for sources of experimental error which, according to Lazar, could explain the "unusual results". In his letter to Le Monde, Benveniste complains that this is what he has tried to do.

The affair, says Benveniste, will "finish badly, in the utmost banality", implying that foreign researchers will now take the glory if his results are supported. "I have sometimes fantasized", he says. "I did not then know that physicists who deal with infinity have the right to dream, but that soft savants like biologists do not! Now I know."

Peter Coles

\section{Researchers win pay} awards in States

\section{Washington}

US GOVERNMENT researchers and scientific administrators will benefit from the executive-level salary rise proposed in a bill sent to Congress last week by President George Bush. The bill sets out pay rises of between 8 and 25 per cent for top federal employees, and creates a special salary category that would pay up to $\$ 124,400$ to workers in 200 positions requiring "specialized and critical skills".

The low pay offered by government positions compared with those in private industry has meant high turnover and difficulty in filling senior scientific and technical posts in recent years. Half a dozen top researchers have left the US National Aeronautics and Space Administration since the beginning of the year, giving low pay as one of the reasons. And many government agencies are regularly turned down by a dozen or more prospective employees before they can fill highlevel research jobs.

Legislation to raise salaries was introduced by Congress earlier this year but was voted down because it would also have given legislators a politically controversial 50 per cent pay increase (see Nature 337, $588 ; 1989$ ).

Carol Ezzell

\section{... and in France}

Paris

Discussions between the French research minister and unions representing researchers in the state institutes, which began in March this year, have ended in a package of pay increases and promotion opportunities. Remarkably, both parties are apparently happy with the outcome of negotiations. The FF370-million (\$59.2 million) deal affects some 15,000 researchers and 25,000 technicians and administrators and comprises improvements in salaries, career prospects, recruitment and opportunities for transfer to teaching posts within universities.

To encourage recruitment of young researchers, the starting salary for a post within one of the state organizations will be raised from $F F 111,600(\$ 17,856)$ a year to FF120,000 $(\$ 19,200)$.

The number of doctoral bursaries, currently valued at FF84,000, will rise by 50 per cent from the present 1,900 . Half of the new grants will be available from September, the remainder next year.

Career prospects have also been improved. The upper age limit for recruitment at the lowest research grade has been set at 31 , but direct entry at the upper end of the basic research scale (chargé de recherche I) will become easier. There is a target of 1,000 new promotions by 1993 half of these by next year. In addition, directors of large laboratories will be eligible for a FF36,000 annual bonus.
Peter Coles 